\title{
Writing strategies by beginning authors of academic genre
}

\author{
Abdul Syahid \\ abdul.syahid@iain-palangkaraya.ac.id \\ Department of English Language Education, Faculty of Teacher Training and \\ Education, Institut Agama Islam Negeri Palangka Raya, Indonesia \\ Jalan G. Obos Kompleks Islamic Center, Palangka Raya 73112, Indonesia
}

Received: September 16, 2018; $\quad$ Accepted: February 4, 2019; Published: March 9, 2019

\begin{abstract}
Aimed at identifying what writing strategies four beginning authors used and examining how these strategies facilitated their writings, a collective case study describing and comparing the beginning authors was carried out to provide insights into the issue. The authors were teachers of English in English departments at four Indonesian universities, and were selected on the basis of a recommendation by the editor of some books in which their written products were published. To gain a far better understanding of the cases, two data forms (questionnaires and interview notes) were collected. The data gathered were repeatedly examined in order to discover some reoccurring patterns. The inductive process delineated the strategies used by the participants when dealing with academic writing. The results show that, in order of priority, the writing strategies employed in their initial writing careers were social, affective, compensation, and cognitive ones. This study contributes to the knowledge of social or contextual factors in writing English academic papers by illustrating which strategies were used and how in order to cope with the writing process. It also suggests writing strategies be adopted by future authors and built in the classes of English as a foreign language.
\end{abstract}

Keywords: second/foreign language writing; academic writing; academic genre; writing strategies

How to cite this paper: Syahid, A. (2019). Writing strategies by beginning authors of academic genre. Journal on English as a Foreign Language, 9(1), 20-41. doi:http://dx.doi.org/10.23971/jefl.v9i1.952

DOI: http://dx.doi.org/10.23971/jefl.v9i1.952

Journal on English as a Foreign Language, 9(1), 20-41

Copyright @ 2019 by JEFL, p-ISSN 2088-1657; e-ISSN 2502-6615 
English is of great importance in the globalized world. Since the 21st century dawned, English has widely been considered a global language (Crystal, 2012; Warschauer, 2002). As the most extensively and intensively studied second language around the world (Cummins \& Davison, 2007, p. xxiii), it is used by 1 out of 4 people in the world (British Council, 2013) for many purposes, for instance, in the field of education, science and technology. In developing countries such as Indonesia, English is a means of national development by an exchange of information, knowledge and technology (Lauder, 2008). The importance of English is thus undeniably measureless.

Because of the immeasurable significance of English for exchanging academic ideas, even many non-English medium universities have asked their graduate students to write in English. The writing tasks for those whose English is not their L1 are journal articles and theses/dissertations, among other things (Paltridge, 2018). In Indonesia, for example, the General Directorate of Higher Education of Education and Cultural Ministry made an announcement stating a prerequisite for earning a Doctor degree, i.e. publishing an academic paper in an international journal.

In addition, nowadays many researchers who have little or no interest in publishing their work in English should learn to write in English or collaborate with other researchers whose English proficiency meets the requirements (Leki, Cumming, \& Silva, 2008). In order to be publishable and reach a much wider scope of readership in terms of the body of knowledge in general, the papers must be written in English. Under such pressure, it is of interest to investigate how some scholars have begun their journey of academic genre using English as Foreign Language (EFL).

From the very first, writing is a learned and planned undertaking. It is culturally such a specific learned behavior, as Brown (2001, p. 334) puts it, that it can be acquired only if consciously taught. Even though the "what and how" of writing are learned, there is no guarantee that these can be mastered because writing relies on multifaceted language skills. From multiple perspectives of expression, cognition, situation, completion, ideology and society, as Hyland (2016) concludes, writing is a creative act involving a thinking process to show a contextual performance in the form of rule-structured objects aimed at a power related specific community. Unsurprisingly, many scholars such as Cahyono and Widiati (2011) hold the view that writing is the most complex language skill among the four language skills. Thus, writing is not a spontaneous skill or easily acquired. 
In one sense, writing skills possibly depend on the outside world or external factors. As writing must be learned, how it is taught from micro- to macro educational point of views could also affect those who want to express their ideas and feelings in written forms. In the Indonesian context, to make it worse, the contributing factor in the Indonesians' lack of ability to write could be not only the teaching of writing in English, but also that writing in Indonesian has been overlooked at all levels of education, failing to lay the foundations for academic writing (Alwasilah, 2010). So it is quite improbable that such a context could give birth to good writers.

On the one hand, writing in a foreign language will force those who want to do it to encounter some enigmatic differences between their native language and the newly learnt one. On a superficial level, writing in a native language (L1) and that in a second/foreign one (L2) are similar in their broader outlines in terms of planning, writing, and revising. However, a more rigorous closer examination of writing in L1 and that in L2, viewed from six schools of thought, i.e. contrastive rhetoric (reformulated as intercultural rhetoric), a genre approach, empiricism, cognitivism, pragmatism, and critical pedagogy, reveals relatively obvious differences (Atkinson, 2018). In a descriptive study of Chinese and English writing by Chinese writers, Yingli (2012) showed some important differences in the levels of lexicon, sentence, and passage. Cumming has suggested that L2 writing involves elemental dimensions of the text features, composing businesses, and sociocultural contexts, each having microand macro stances. Thus, L2 composition comes about from either a relatively local, episodic, or individual basis; or, from a more global, sequential, or holistic perspective (2001, p. 2). Because of such complexities, L2 writing means more demanding tasks.

The fact that L2 writing is more demanding has been proved by several researchers. Tillema, van den Bergh, Rijlaarsdam, and Sanders (2013), for example, found that 20 Dutch students who were 14 and 15 years old wrote eight essays significantly better in Dutch (L1) than they did in English (L2). In a larger study involving more than 200 students who majored in diverse fields of study, Eckstein and Ferris (2018) showed L2 writers' lower scores, more errors, and weaker vocabulary on their essays. Consequently, writing in L2 is much more complicated than that in L1.

L2 writing is hard for not only EFL primary/secondary school students but also graduate ones. The EFL graduate students usually find English writing the most critical skill they have to master in order to communicate with other scholars in a certain field and get recognized as members of an international 
scholarly community (Sun \& Chang, 2012, p. 44). Besides the innate complexities in writing, particularly in the EFL one, and a set of established conventions of academic composing, non-native English-speaking writers also have to define their identities of academic writers endorsed by their linguistic and rhetorical abilities to take part in a variety of scholarly composing activities (Casanave, 2002; Hyland, 2002). In practice, the academic genre has some characteristics shared by members of academic culture to distinguish it from other genres in terms of objectives, organization, and specific linguistic attributes (Hyland, 2009b, p. 15). Such genre specific features arguably pose a larger challenge.

Furthermore, the praxis of writing in the academic genre is composed of the author's inner and outer realms. In the first realm, academic writing is a complex blend of the authors' L1 and L2 learning journeys as well as disciplinary content knowledge (Yoon, 2008). In the second realm, the authors not only simply report their research or express their concepts neutrally but also use the rhetorical resources to share some insight in a scholarly genre and community by selecting proper words to make the members of academic audiences drawn in, influenced and persuaded (Hyland, 2002, p. 1093). Both of the realms must certainly be well-balanced in order to convey academic meaning.

Writing in the academic genre is a dialog between the author as a scholar and readers as other scholars about the author's efforts to bridge a gap in a certain field. The academic genre such as journal articles, book chapters, conference proceedings, and academic web blogs (Gaillet \& Guglielmo, 2014) are presentations made by a scholar as a member of an academic community for other members. Using academic-specific language, the presentations deal with how a topic of inquiry is framed and understood by presenting a general panorama of past-to-present development in the field to contribute to the creation of knowledge (Hyland, 2009a). Additionally, the author must make every word count (Norris, 2016) by developing the competence to amalgamate one type of knowledge with other ones to write a linguistically accurate and socially appropriate discourse (Bruce, 2010, p. 1). Therefore, the non-native English authors must journey across L1, L2 (EFL in this study), and the expectations embedded in an academic genre.

The emerging authors in this study are those who have published some of their English academic written products as: articles in local journals or in their own blogs, papers presented at conferences, or books published by a national publishing house. They have written 6-13 research based or conceptual 
articles. Because of their rather limited number of scientific articles, they were classified as beginning authors.

In addition, it is of importance to realize that they were not given particular writing assignments by their lecturers in a school setting, but more engaged to write on their own as a part of their professional development. They acknowledged well the difference between what their professors' demand and busy readers want. The latter want nuggets of precious information. Based on their works, it can be assumed that they have a greater chance to be internationally acknowledged when their works are published in international reputable journals. Their strategies to overcome difficulties in meeting the demands, conventions, and expectations of the academic genre in their initial writing careers are undeniably worth investigating.

As stated before, the EFL writing academic genre is so complex that beginning authors have to develop effective strategies for managing the EFL writing process in the genre. Strategy itself is defined as a series of procedures to achieve a certain goal (Richards \& Schmidt, 2010, p. 569). Writing strategy in the present study means the procedures to produce an EFL research-based or conceptual article by orchestrating a special purpose, a writing organization, certain linguistic characteristics, and disciplinary content knowledge with the aim of sharing meanings with the members of academic audiences.

Underlain by the writing-as-process model which views writing as a series of recursive activities until the final product is presented (Cahyono \& Widiati, 2011, p. 73), the present study tries to examine a relatively unexplored area of EFL writing, particularly the writing of academic genre in an EFL context. The study, therefore, tries to reach refined conceptualizations of the EFL writing strategies. Even though there have been many studies of the scholarly genre, as (Belcher, 2006) notes, most of them have gazed more at products rather than processes. From 1992 to 2016, moreover, only 17 out of 272 articles $(6.3 \%)$ on the writing processes were identified in the Journal of Second Language Writing (Riazi, Shi, \& Haggerty, 2018). For that reason, this study could provide considerable insight into the composing processes which also include writing strategies.

Writing strategies employed by L2 writers are generating considerable interest. Investigating different writing strategies by English and Indonesian writers used in research articles, Mirahayuni (2002) found that new organizing strategies employed by the Indonesian writers were uncommon for written work in both English and Indonesian languages. Investigating the strategies on 
writing by successful and less successful EFL learners along with the correlation between their strategy use and success at Hanoi University in Vietnam, Nguyen (2009) concludes that the better EFL writers were at composing EFL texts, the more they used writing strategies in terms of frequency and variation. Another related investigation is on a famous author's educational endeavor to improve his EFL writing competence that contributed to his success of becoming an academician, an author, a scientist, a literary critic, and a culturist (Prijambodo, 2009). Writing strategies consequently play a pivotal part in writing success.

Even though those researchers have dealt with L2 writing strategies, the main weakness in their studies is that they tend to ignore beginning authors when writing about the EFL academic genre outside of a classroom setting. They also offer no explanation for the writing strategies adopted by the emerging scholars to overcome the difficulty of L2 writing. Given that there is still a need for understanding L2 writing strategies adopted by emerging authors of scholarly writing, this study was undertaken to identify what L2 writing strategies were adopted by the four beginning authors and to examine how the strategies facilitated their writings.

Two questions were, therefore, addressed. Firstly, what were the writing strategies used by the beginning authors of EFL speakers? Secondly, how did the writing strategies facilitate the writing process?

To date, those strategies have received scant attention in the research literature. Since 1992 not more than 17 articles have been published on writing strategies, including the process of revising, noticing, planning, restructuring, formulating, and publishing (Riazi et al., 2018, p. 47). A systematic understanding of how the emerging scholars rise to the challenge of L2 academic writing is still lacking. It is hoped that this research will contribute to a deeper understanding of strategies adopted by emerging scholars when writing in an L2 scholarly genre.

Driven by the first research question, the aim of the study was to identify what writing strategies four beginning authors used. Motivated by the second question, this study is also aimed at examining how the writing strategies assisted the beginning authors in their writing. The answers to these questions could possibly provide other emerging scholars or L2 writers with some information that may enlighten them. 


\section{METHOD}

To answer the questions, this study was conducted as a multiple-case one using the procedures described by Duff (2008), i.e. identifying the research as an issue, asking research questions and drawing ethical guidelines. In the first stage, once the data were collected and stored, analytical statements were generated and tested. The statements were then interpreted or explained in order to decide on the outcome. The case report was written and/or revised until it was ready for the publication phase. Such procedures were followed because they were technically and economically feasible.

Informed by the literature discussed and driven by the research questions addressed, the criterion for selecting participants was that they be EFL speakers who had published at least three English articles either in national journals or on the net. A professor of English language teaching, who had edited some articles and books written by EFL speakers, then recommended participants who fit this criterion. The participants were trusted to give reliable and accurate information, which comprised the data.

In total, four EFL teachers holding Master degrees in teaching EFL at four different Indonesian universities were invited to participate in this study. Their pseudonyms are Adid, Mary, Kasih, and Cita. All of them but Adid are female. All of them have presented their papers in, at least, two international conferences on Teaching English as a Foreign Language (TEFL). They also have published their papers in Indonesian journals in English Language Teaching. In addition, Adid's articles have been published as a book by a national publishing house and Mary received a government grant to publish her thesis as a book. They can therefore be considered qualified to advance understandings about the writing strategies employed by EFL writers, especially emerging scholars.

Given that Kasih and Cita lived in Malang (East Java) but Adid and Mary lived in two other cities, i.e. Cirebon (West Java) and Tulungagung (East Java), most of the data were gathered using questionnaires by email and structured interview by phone. The first instrument was used to gather both information about their personal data, academic works, and composing process. For information about written products and the writing process itself, the questions were posed on a 4-point Likert scale with response choices of "never", "rarely", "frequently", and "always".

The process items were divided into four main parts. The first part dealt with the process of before (pre) writing (13 items). The next one concerned the process of while (during) writing (13 items). The last two parts covered the 
processes of after (post) writing (6 items), and after the work is published/presented (post-publishing) (4 items). The questionnaire used in this study was adapted from Nguyen (2009).

Adapted from Nguyen (2009) and Prijambodo (2009), the second instrument (Appendix 1) made use of in this study was a semi-structured interview (Hyland, 2002; Mackey \& Gass, 2016). In the first section, the three items were to clarify the participants' confusion, if any, over the questionnaire, and to find out if there were any other strategies not included there. In the second section, the twenty-two open questions were aimed at better understanding of the questionnaire content and their writing strategies.

Based on a TEFL professor's written corrective feedback on some unrelated items in the survey and irrelevant questions in the protocol interview, those questions inappropriate to the writing strategies were excluded. Moreover, two graduate students of EFL were invited to pilot the two instruments. They were chosen because they were comparable to the participants in the study. Two senior high school students were also invited to ensure question clarity as the interview would be set up by phone.

Data were gathered over two months, i.e. the questionnaire given in the first month and the interview in the second. Responses were then analyzed by using two techniques, i.e. the tabulation and the coding process. Following Nguyen (2009), seven learning strategies, i.e. Memory, Cognitive, Compensation, Metacognitive, Affective, Social, and Negative, were used as the basis for coding analysis. Each response to the questionnaire was on a fourpoint Likert scale and organized according to one of the learning strategies. After the interviews were transcribed, the data were analyzed for content. The techniques of qualitative data analysis were carried out using the framework proposed by Dörnyei (2007), i.e. the pre-coding step and the coding process.

\section{FINDINGS}

To present the results more clearly, this section is divided into two parts. In the first part, the results from the questionnaire will be shown. They deal with the first research question, i.e. the strategies employed by the participants before, while, and after writing along with those after publishing. In the second part, the qualitative data from the follow-up interviews are presented. These show how the strategies revealed in the writing process section relate to the research findings. 


\section{The Adopted Writing Strategies}

The questionnaires completed by the participants were analyzed using the following criteria: to categorize strategies as ones adopted by them, three out of the four chose either "often" (O) or "always" (A). On the other hand, to categorize strategies as unemployed, three out of four participants chose either "rarely" (R) or "never" (N). In this case, S standing for "sometimes" was used as the middle category.

As can be seen in Table 1, in the phase of before writing, three participants studied at home, work, or other places; read their lesson notes, handout, books, journals, etc. before writing; paid attention to the feedback related to their previous writing; paid attention to the instructions given by their lecturers or guidelines in a scholarly journal before writing; used their background knowledge to help elaborate their ideas; wrote the outlines of organization in English; and tried to find a comfortable, quiet place in order to get focused. It is noteworthy that the participants did not search information and make notes in the Indonesian language. They did not think about the organization of their writing in Indonesian before writing either. Cognitive strategies were thus not employed. In this phase, it was found that they employed various other strategies, i.e. metacognitive, memory, and affective.

Table 1. Pre-writing Strategies

\begin{tabular}{clcccc}
\hline \multirow{2}{*}{ No. } & \multicolumn{1}{c}{ Questions } & \multicolumn{3}{c}{ Participants } \\
\cline { 2 - 6 } & & 1 & 2 & 3 & 4 \\
\hline 1 & I study at home, work, or other places. & $\mathrm{O}$ & $\mathrm{O}$ & $\mathrm{S}$ & $\mathrm{O}$ \\
\hline 2 & $\begin{array}{l}\text { I read my lesson notes, handout, books, journals, etc. } \\
\text { before writing. }\end{array}$ & $\mathrm{A}$ & $\mathrm{S}$ & $\mathrm{O}$ & $\mathrm{O}$ \\
\hline 3 & $\begin{array}{l}\text { I pay attention to the feedbacks related to my previous } \\
\text { writing. }\end{array}$ & $\mathrm{A}$ & $\mathrm{A}$ & $\mathrm{S}$ & $\mathrm{A}$ \\
\hline 4 & $\begin{array}{l}\text { I pay attention to the instructions given by my lecturers } \\
\text { or guidelines in a scholarly journal before writing. }\end{array}$ & $\mathrm{A}$ & $\mathrm{A}$ & $\mathrm{S}$ & $\mathrm{A}$ \\
\hline 5 & $\begin{array}{l}\text { I discuss what I am going to write with other people } \\
\text { (classmates, lecturers, colleagues, etc.). }\end{array}$ & $\mathrm{S}$ & $\mathrm{R}$ & $\mathrm{S}$ & $\mathrm{S}$ \\
\hline 6 & $\begin{array}{l}\text { I brainstorm my ideas (create a list including a wide } \\
\text { variety of related ideas) and write notes. }\end{array}$ & $\mathrm{A}$ & $\mathrm{S}$ & $\mathrm{R}$ & $\mathrm{A}$ \\
\hline 7 & $\begin{array}{l}\text { I use my background knowledge to help me to elaborate } \\
\text { my ideas. }\end{array}$ & $\mathrm{A}$ & $\mathrm{O}$ & $\mathrm{O}$ & $\mathrm{A}$ \\
\hline 8 & $\begin{array}{l}\text { I search information and make notes in Bahasa Indonesia } \\
\text { before writing. }\end{array}$ & $\mathrm{R}$ & $\mathrm{R}$ & $\mathrm{R}$ & $\mathrm{R}$ \\
\hline 9 & $\begin{array}{l}\text { I think about the organization of my writing in Bahasa } \\
\text { Indonesia before writing. }\end{array}$ & $\mathrm{R}$ & $\mathrm{R}$ & $\mathrm{N}$ & $\mathrm{R}$ \\
\hline
\end{tabular}

Journal on English as a Foreign Language, 9(1), 20-41

Copyright (C) 2019 by JEFL, p-ISSN 2088-1657; e-ISSN 2502-6615 


\begin{tabular}{llllll}
\hline \multirow{2}{*}{ No. } & \multicolumn{1}{c}{ Questions } & \multicolumn{3}{c}{ Participants } \\
\cline { 3 - 6 } & & 1 & 2 & 3 & 4 \\
\hline 10 & I write the outlines of organization in English. & $\mathrm{A}$ & $\mathrm{A}$ & $\mathrm{S}$ & $\mathrm{O}$ \\
\hline 11 & I like to start writing immediately without any plan. & $\mathrm{R}$ & $\mathrm{S}$ & $\mathrm{O}$ & $\mathrm{O}$ \\
\hline 12 & I make a timetable for the writing process. & $\mathrm{A}$ & $\mathrm{N}$ & $\mathrm{S}$ & $\mathrm{O}$ \\
\hline 13 & $\begin{array}{l}\text { I try to write in a comfortable, quiet place in order to get } \\
\text { focused. }\end{array}$ & $\mathrm{A}$ & $\mathrm{O}$ & $\mathrm{S}$ & $\mathrm{A}$ \\
\hline
\end{tabular}

In the while-writing stage, as highlighted in Table 2, all of the employed strategies belong to compensation ones only, i.e. using a dictionary to check something in work which was not clear for them before or when they wrote; checking or editing the grammar, vocabulary, spelling, and punctuation; checking or editing the writing organization; using an English-English dictionary. In this stage, they also preferred writing their drafts directly in English as opposed to writing in their L1 first and translating them into English. They used a dictionary until they finished writing their drafts. They did not use a grammar book to check something unclear to them before or when writing either. Therefore, the unemployed strategies cover the cognitive domain.

Table 2. Whilst-writing Strategies

\begin{tabular}{|c|c|c|c|c|c|}
\hline \multirow{2}{*}{ No. } & \multirow{2}{*}{ Questions } & \multicolumn{4}{|c|}{ Subject } \\
\hline & & 1 & 2 & 3 & 4 \\
\hline 1 & $\begin{array}{l}\text { I like to write my draft in Bahasa Indonesia first and } \\
\text { translate it into English }\end{array}$ & $\mathrm{N}$ & $\mathrm{N}$ & $\mathrm{N}$ & S \\
\hline 2 & I like to write two or more drafts. & $\mathrm{O}$ & $\mathrm{R}$ & $\mathrm{R}$ & $\mathrm{O}$ \\
\hline 3 & I like to write just one draft & $\mathrm{R}$ & $\mathrm{O}$ & $S$ & $\mathrm{O}$ \\
\hline 4 & I like to edit my work while I am writing. & $\mathrm{S}$ & $\mathrm{O}$ & $S$ & $\mathrm{~S}$ \\
\hline 5 & $\begin{array}{l}\text { I like to edit my work when I have finished writing my } \\
\text { draft. }\end{array}$ & $\mathrm{A}$ & $\mathrm{S}$ & $\mathrm{O}$ & $\mathrm{S}$ \\
\hline 6 & $\begin{array}{l}\text { I use a dictionary to check something in work which is not } \\
\text { clear form me before or when I write. }\end{array}$ & A & A & $\mathrm{O}$ & $\mathrm{O}$ \\
\hline 7 & I do not use a dictionary until I finish writing my draft. & $\mathrm{R}$ & $\mathrm{R}$ & $\mathrm{R}$ & $\mathrm{S}$ \\
\hline 8 & $\begin{array}{l}\text { I use a grammar book to check something in work which is } \\
\text { not clear form me before or when I write. }\end{array}$ & $\mathrm{R}$ & $\mathrm{R}$ & S & $\mathrm{R}$ \\
\hline 9 & I do not use a grammar book until I finish writing my draft. & $\mathrm{R}$ & $\mathrm{O}$ & $\mathrm{R}$ & $\mathrm{O}$ \\
\hline 10 & $\begin{array}{l}\text { I check or edit the grammar, vocabulary, spelling, and } \\
\text { punctuation. }\end{array}$ & A & A & $\mathrm{R}$ & $\mathrm{O}$ \\
\hline 11 & I check or edit the organization of my writing. & A & A & $S$ & $\mathrm{O}$ \\
\hline 12 & $\begin{array}{l}\text { I use an English - Bahasa Indonesia, Bahasa Indonesia } \\
\text { dictionary (bilingual) }\end{array}$ & $\mathrm{R}$ & $\mathrm{O}$ & $\mathrm{O}$ & S \\
\hline 13 & I use an English-English dictionary. & A & $\mathrm{O}$ & $\mathrm{O}$ & $\mathrm{O}$ \\
\hline
\end{tabular}


The same pattern took place in the phase of After Writing. As can be seen in Table 3, the emerging authors tended to go back to their writing to reedit or revise the contents (ideas) and the organization of their writing. As in the previous writing stage, compensation strategies were predominantly used.

Table 3. Post-writing Strategies

\begin{tabular}{llllll}
\hline \multirow{2}{*}{ No. } & \multicolumn{1}{c}{ Questions } & \multicolumn{4}{c}{ Subject } \\
\cline { 3 - 6 } & & 1 & 2 & 3 & 4 \\
\hline 1 & I go back to my writing to edit or change the contents (ideas) & $\mathrm{O}$ & $\mathrm{O}$ & $\mathrm{R}$ & $\mathrm{O}$ \\
\hline 2 & $\begin{array}{l}\text { I go back to my writing to edit or change the grammar, } \\
\text { vocabulary, spelling, and punctuation. }\end{array}$ & $\mathrm{A}$ & $\mathrm{S}$ & $\mathrm{S}$ & $\mathrm{S}$ \\
\hline 3 & I go back to my writing to edit the organization of my writing. & $\mathrm{A}$ & $\mathrm{O}$ & $\mathrm{S}$ & $\mathrm{O}$ \\
\hline 4 & $\begin{array}{l}\text { I discuss my work with other people (classmates, lecturers, } \\
\text { colleagues, etc.) when I have finished. }\end{array}$ & $\mathrm{S}$ & $\mathrm{R}$ & $\mathrm{S}$ & $\mathrm{S}$ \\
\hline 5 & $\begin{array}{l}\text { I do not look at my work anymore when I have finished -it is } \\
\text { completely finished. }\end{array}$ & $\mathrm{R}$ & $\mathrm{O}$ & $\mathrm{S}$ & $\mathrm{O}$ \\
\hline 6 & I give myself a reward when I have finished. & $\mathrm{A}$ & $\mathrm{S}$ & $\mathrm{N}$ & $\mathrm{O}$ \\
\hline
\end{tabular}

After their academic work was published, all the beginning authors did was to make some notes or remember the feedback they got for their work. As shown in Table 4, they did nothing else. The only strategies used were compensation strategies.

Table 4. Post-publishing Strategies

\begin{tabular}{llllll}
\hline \multirow{2}{*}{ No. } & \multicolumn{1}{c}{ Questions } & \multicolumn{3}{c}{ Subject } \\
\cline { 2 - 5 } & $\begin{array}{l}\text { I make some notes or remember the feedback I get for my } \\
\text { work. }\end{array}$ & $\mathrm{A}$ & $\mathrm{O}$ & $\mathrm{S}$ & $\mathrm{A}$ \\
\hline 2 & $\begin{array}{l}\text { I record the types of errors I made (e.g. grammar, } \\
\text { vocabulary, and organization). }\end{array}$ & $\mathrm{S}$ & $\mathrm{N}$ & $\mathrm{A}$ \\
\hline 3 & $\begin{array}{l}\text { I discuss the feedbacks to improve the other language skills } \\
\text { (listening, speaking, and reading) }\end{array}$ & $\mathrm{A}$ & $\mathrm{R}$ & $\mathrm{S}$ & $\mathrm{O}$ \\
\hline 4 & I do not remember the feedbacks. & $\mathrm{N}$ & $\mathrm{S}$ & $\mathrm{R}$ & $\mathrm{S}$ \\
\hline
\end{tabular}

The results would seem to indicate that in the pre-writing phase the participants employed various strategies, i.e. metacognitive, memory, and affective. In addition, these results suggest that the strategies employed in the next three writing stages were compensation strategies only. The results from the questionnaire showed which writing strategies were employed; the results from the structured interview would answer how the strategies facilitated the writing. 


\section{Writing Strategies to Facilitate and Improve Writing}

In the first part of the interview protocol, the four participants were asked if there were any items vague for them or any other writing strategies not covered yet in the self-answered questionnaires. All of them confirmed that no ambiguity in the questionnaire was detected that could affect their answers. Two of them also conveyed other strategies not previously revealed. Adid shared his strategy to avoid plagiarism by translating into Indonesian as well as paraphrasing. He furthermore expressed his concern about it by saying, "Lots of students have plagiarized. They do copy and paste without knowing what it means". Finally, Kasih put an emphasis on simple and applicable things as the point of departure in her writing academic genre.

The next part of the interview showed that the three participants began their writing career when they joined a graduate program in TEFL but Kasih did when she was doing her undergraduate degree. Despite the different levels, all of them wrote their first academic genre for a TEFL-related conference and writing competition. Cita added that the reason she wrote for a conference and her blog was "To get it read. To get feedback." How significant social strategies employed by the participants were is also worth underlining. The three participants considered one of their written products most impressive because of being presented in a conference (Adid), being most intensively reviewed by the writing instructor (Mary), and being considered inspiring by a reader (Kasih).

Different impressions of their first academic genre, including lack of selfconfidence, being a burden, and difficulties in elaborating the main idea were reported. Her lecturers' support with Kasih's first paper was extremely impressive for her as she said, "It helped me very much because of my limited grammatical and diction competence." At the outset of their journeys, Adid, Kasih and Cita dealt with affective strategies. Furthermore, the topics they chose were based on their personal interests. Mary, who had never taken a deep interest in writing, on the other hand, took a certain topic of interest because of the courses she was assigned to teach.

It can also be inferred that none of them wrote other texts in English to practice EFL writing skills. They considered writing in the genre a writing practice. "... practice writing by doing it. I did not devote my energy to the writing practice," said Adid. Ranging from one week to one semester, Adid, Mary, and Cita thought that it was their moods that actually determined the duration of the writing process and yet, for Kasih it was the publishing target. She, furthermore, said, "I have written without setting a target for a conference

Journal on English as a Foreign Language, 9(1), 20-41

Copyright (C) 2019 by JEFL, p-ISSN 2088-1657; e-ISSN 2502-6615 
... just for the sake of writing, but this writing has never been finished." Moreover, when describing and explaining any factors that affected their English writing, all of them acknowledged affective strategies in terms of choosing preferred time and place to write in order not to be disturbed by people around them and to build the proper mood. Mary, for example, wrote in another city where she could focus. She further said, "I do not know, after getting my doctoral degree in Malang, if I have time to write." Thus, the role of affective strategies is very crucial for them and so is that of social ones.

The difficulties they usually faced when writing in an EFL academic genre were reading skills in terms of analyzing literature, lack of related literature, the choice of research design, and the tendency to use long sentences resulting in some grammatical errors. Synthesizing, browsing the internet, going to library, reviewing nonnative authors' literature, simple sentence paraphrasing, proof-reading, the use of dictionaries (electronic \& paper based) were used as coping strategies. The participants, therefore, used more than one strategy, i.e. cognitive, metacognitive, social, and compensation ones.

Nevertheless, when finding themselves out of ideas, most of them preferred a cognitive strategy, i.e. reviewing related literature, while Kasih preferred social strategy, i.e. discussing it with her campus mates and colleagues and corresponding with some pen pals of native TEFL/TESL practitioners by email. Cita also added that she quit writing for a while to refresh her mind (metacognitive strategy).

Before writing, Mary and Cita stated that they read about the themes they were going to write about because it helped build knowledge and find related theories. Besides doing this, Adid also thought of the research design by which his idea could be applied as a point of departure in the writing process.

Two participants used a cognitive strategy of thinking of an idea in Indonesian to elaborate the main idea. In addition, Kasih said, "I wrote in Indonesian setting." Adid reported, on the other hand, that he thought in English as he was accustomed to it and it was easier for him. Despite the difference, on the whole, they wrote immediately in English because of being easier, simpler, and faster. " .... If I have to translate my writing, wow, double trouble," said Mary.

Finally, it is the affective strategy that drove them to continue writing academic English. "... Teachers are duty-bound to write," answered Mary. Kasih commented that it is a part of her self-reflection as a lecturer. In line with this, Adid asked for a considerably lightened workload as a lecturer, “... 
Tiredness put me in a bad mood." All of them were self-motivated to carry out writing in the English academic genre. Adid, for instance, took part in two online writing workshops while Mary tried her best to get her writing published by a reputable international journal.

As can be seen, the results obtained from the questionnaire corroborate the findings of the in-depth interviews. Based on such results from the two instruments, corroboration for the writing strategies employed by the participants is relatively high. It is clear that the main coping strategies employed by the participants are associated with social, affective, compensation, and cognitive domains.

\section{DISCUSSION}

This study, with its limitations such as the data collection method and the moderation of the coding process for the sake of time, has suggested how the beginning authors went through all of the stages of the writing process, from pre-writing to publishing. The strategies employed by the beginning authors can be categorized into social, affective, compensation, and cognitive strategies.

\section{Social Strategies}

Based on the recurring patterns in the previous section, a striking similarity can be found: the main strategy employed by all of the participants was social, i.e. writing for publication. Despite considering such writing a burden, setting the writing forum as a target got the participants thinking about other strategies such as choosing the proper place and time of writing. How very strongly they felt about it is a sentiment shared by Casanave $(2002$, p. 84) who stated that not only her diploma but also being actively involved in some public forum, conferences, and journals had raised her sense of authority in the field. In this case, a forum in which the participants could present the academic genre plays the most crucial aspect to give birth to the beginning authors. For this reason, workshop environments could be useful for the learners to have peer support and supportive chances of discussing their writing-in-progress, along with raising their awareness that attention to audience is vital (Hyland, 2009, p. 92).

That the social strategies were the primary ones used by the emerging scholars in this study would seem to imply that social interaction played a vital role in enhancing their self-confidence. Feeling good about their work in some public forum, conferences, and journals was quite necessary because, as they 
admitted, they had written in solitude. As it was hard for them to find peerreview and feedback even if they asked for, they rarely consulted their colleagues about what they were writing about. Even though solitude is often needed by some academics in order to improve their writing concentration (Barton \& McCulloch, 2018), writing forums could engage the beginning authors from the pre-writing to post-publishing phases.

\section{Affective Strategies}

An interesting point to consider is that the teaching of writing at the undergraduate level seemingly did not motivate them to write the genre outside of the tasks given in a writing course. The question is also raised by Casanave (2002, p. 35) when remembering how wretchedly difficult her writing experience in college was due to lack of practice, knowledge of a writing topic, interest in the assigned tasks, or mentoring. A salient and similar finding from this study was that all of the participants considered their moods the most dominant factor in achieving the target. Other relevant affective factors included how long the writing preparation and the finishing process took, along with how undisturbed the writing environments were for them. It is certainly true that, considering all the affective factors while writing, they felt stressed and anxious enough to quit writing. Indeed, in reviewing literature on how well graduate students wrote professional articles, Ondrusek (2012, p. 182) reveals that the emotional side to writing generates an additional set of unique obstacles.

Furthermore, three participants indicated that they wrote because the topics were interesting for them. In a similar vein, Xinghua (2010, p. 52) argues that being personally involved in the writing process resulted in being more productive along with greater fluency and satisfaction whereas being objectified had the opposite effect. By recognizing the crucial role that affective factors such as self-efficacy have played for L2 writing as suggested by Sasaki (2000, p. 283) and Zabihi (2018), this study is relevant to the growing effort to develop a more comprehensive model of the $\mathrm{L} 2$ writing process.

\section{Compensation Strategies}

Phakiti and Li (2011, p. 242) articulate the difficulty foreign graduate students had in L2 writing at an Australian university. 51 students majoring in Teaching English to speakers of other languages encountered problems such as composing an extensive text and synthesizing ideas, caused by diverse composition methods between the L1 and English. Moreover, in a comprehensive review of previous research on L2 writing, Jun (2008) finds that

Journal on English as a Foreign Language, 9(1), 20-41

Copyright (C) 2019 by JEFL, p-ISSN 2088-1657; e-ISSN 2502-6615 
in the complex L2 composing process some factors must also be considered. Besides the lack of certain L2 knowledge, this had the effect of making all of the participants apply such compensation strategies as going back to their writings for editing and changing some relatively unessential aspects such as spelling and punctuation, but leaving the main concepts untouched. Such strategy as reading some related articles by non-native writers to facilitate their understanding of theories was also adopted in order to cope with their writing difficulties.

\section{Cognitive Strategies}

The fourth major category of writing strategies found in this study was cognitive ones, including extensive reading. Such reading was mostly used for generating ideas. Related to this, in her research on writing academic genre, Casanave (2002, p. 71) expresses that in their final questionnaire some students commented on how valuable regular and extensive reading was. In line with this, when studying three Chinese EFL graduate students' knowledge about L2 writing, $\mathrm{Mu}$ and Carrington (2007) also found that the students used the strategy for the purpose of searching for further information to facilitate their being more familiar with the target field, to get more ideas as needed to suit the requirements for their entry to the target academic community, and to learn idiomatic expressions of their research field. In this study, extensive reading was employed to conquer being fresh out of ideas, as well as difficulties in grammar and content.

\section{CONCLUSION}

As can be seen, the results of the data analysis demonstrate that all of the subjects employed a wide range of writing strategies. The ways the beginning authors coped with the complexities of writing in the English academic genre can be categorized into four strategies in order of priority, i.e. social, affective, compensation, and cognitive ones. The main point that emerges from this study is that the social and affective strategies are more often used than the other two strategies. It indicates that writing is a socio-affective act closely related to a certain audience, purpose and the emotional processes of composing the text itself. The socio-affective strategies such as writing forums and conferences or journal writing, along with moods such as a quiet environment, determine the use of both compensation strategies for overcoming any gap in knowledge of the language and cognitive ones for increasing the efficiency of writing competence, knowledge acquisition, and the volume of information obtained through deeper information processing. 
The findings suggest that teachers of English devote class-time to student-teacher conferences for reflection and/or self-assessment practices. Such activities are also aimed at encouraging learners to talk about their drafts with the teachers or with fellow students for corrective feedback. In addition, the learners' feelings, motivation, and attitudes related to writing can be boosted by such varied factors as highly relevant or surprising or unexpected information, an environmental change, and the teacher's enthusiasm. As shown above, the two chief writing strategies, in turn, facilitate the use of the other two categories.

For English teachers' professional development, the implication is that writing in the academic genre puts great emphasis on the sense of academic conventions, audience and purposes. This undoubtedly influences the teachers' choice of content, style/genre, vocabulary and grammatical forms in order to make their writing academically publishable.

Further research on how a single category of the above writing strategies is used by beginning authors is of great importance to dig deeper into this topic. Finally, it is certainly the case that a longitudinal study in which the beginning authors are studied for a certain time period in order to see how the use of writing strategies changes and develops with time, would be more illuminating.

\section{REFERENCES}

Alwasilah, A. C. (2010). Lamenting language courses in the undergraduate curriculum. 1-5. Leksika, 4(2), 1-5.

Atkinson, D. (2018). Theory in second language writing. In J. I. Liontas, T. International Association, \& M. DelliCarpini (Eds.), The TESOL Encyclopedia of English Language Teaching (pp. 1-6). Hoboken, NJ, USA: John Wiley \& Sons, Inc. https://doi.org/10.1002/9781118784235.eelt0524

Barton, D., \& McCulloch, S. (2018). Negotiating tensions around new forms of academic writing. Discourse, Context $\mathcal{E}$ Media, 24, 8-15. https://doi.org/10.1016/.dcm.2018.01.006

Belcher, D. D. (2006). English for specific purposes: Teaching to perceived needs and imagined futures in worlds of work, study, and everyday life. TESOL Quarterly, 40(1), 133. https://doi.org/10.2307/40264514

British Council. (2013). The English effect. Manchester: British Council. 
Brown, H. D. (2001). Teaching by principles: An interactive approach to language pedagogy (2nd ed.). White Plains, NY: Longman.

Bruce, I. (2010). Academic writing and genre: A systematic analysis. Bloomsbury Publishing.

Cahyono, B. Y., \& Widiati, U. (2011). The teaching of writing. In B. Y. Cahyono (Ed.), The teaching of English as a foreign language in Indonesia (pp. 69-85). Malang: State University of Malang Press.

Casanave, C. P. (2002). Writing games: Multicultural case studies of academic literacy practices in higher education. Mahwah, N.J: Lawrence Erlbaum Associates.

Crystal, D. (2012). English as a global language (Canto Classics edition). Cambridge, UK; New York: Cambridge University Press.

Cumming, A. (2001). Learning to write in a second language: Two decades of research. International Journal of English Studies, 1(2), 1-23.

Cummins, J., \& Davison, C. (2007). Preface. In J. Cummins \& C. Davison (Eds.), International Handbook of English Language Teaching (pp. xxi-xxv). New York: Springer.

Dörnyei, Z. (2007). Research methods in applied linguistics: Quantitative, qualitative, and mixed methodologies. Oxford: OUP Oxford.

Duff, P. (2008). Case study research in applied linguistics. Taylor \& Francis.

Eckstein, G., \& Ferris, D. (2018). Comparing L1 and L2 texts and writers in firstyear composition. TESOL Quarterly, 52(1), 137-162. https://doi.org/10.1002/tesq.376

Gaillet, L. L., \& Guglielmo, L. (2014). Understanding academic genre. In L. L. Gaillet \& L. Guglielmo (Eds.), Scholarly publication in a changing academic landscape: models for success (First edition, pp. 35-49). New York, NY: Palgrave Macmillan.

Hyland, K. (2002). Authority and invisibility. Journal of Pragmatics, 34(8), 10911112. https://doi.org/10.1016/S0378-2166(02)00035-8

Hyland, K. (2009a). Academic discourse: English in a global context. London; New York: Continuum.

Hyland, K. (2009b). Teaching and researching writing (2 ${ }^{\text {nd }}$ ed.). Harlow: Longman. 
Hyland, K. (2016). Methods and methodologies in second language writing research. System, 59, 116-125. https://doi.org/10.1016/.system.2016.05.002

Jun, Z. (2008). A comprehensive review of studies on second language writing. HKBU Papers in Applied Language Studies, 12, 89-123.

Lauder, A. (2008). The status and function of English in Indonesia: A review of key factors. Makara Human Behavior Studies in Asia, 12(1), 9. https://doi.org/10.7454/mssh.v12i1.128

Leki, I., Cumming, A. H., \& Silva, T. J. (2008). A synthesis of research on second language writing in English. New York: Routledge.

Mackey, A., \& Gass, S. M. (2016). Second language research: Methodology and design ( $2^{\text {nd }}$ ed.). New York: Routledge.

Mirahayuni, N. K. (2002). Investigating generic structure of English research articles: Writing strategy differences between English and Indonesian writers. TEFLIN Journal, 13(1), 22-57. https://doi.org/10.15639/teflinjournal.v13i1/22-57

$\mathrm{Mu}, \mathrm{C}$., \& Carrington, S. (2007). An investigation of three Chinese students' English writing strategies. TESL-EJ, 11(1), 1-23.

Nguyen, T. N. (2009). EFL learners in Vietnam: An investigation of writing strategies (Thesis). Auckland University of Technology. Retrieved from http://aut.researchgateway.ac.nz/handle/10292/751

Norris, C. B. (2016). Academic writing in English. Helsinki: Language Services University of Helsinki.

Ondrusek, A. L. (2012). What the research reveals about graduate students' writing skills: A literature review. Journal of Education for Library and Information Science, 53(3), 176-188.

Paltridge, B. (2018). Graduate student writing. In J. I. Liontas (Ed.), The TESOL Encyclopedia of English Language Teaching (pp. 1-6). Hoboken, NJ: John Wiley \& Sons, Inc. https://doi.org/10.1002/9781118784235.eelt0516

Phakiti, A., \& Li, L. (2011). General academic difficulties and reading and writing difficulties among Asian ESL postgraduate students in TESOL at an Australian university. RELC Journal, 42(3), 227-264. https://doi.org/10.1177/0033688211421417 
Prijambodo, V. L. (2009). The learning experience in EFL writing of an Indonesian writer: A case study on Budi Darma. (Dissertation). State University of Malang, Malang. Retrieved from http:/karyailmiah.um.ac.id/index.php/disertasi/article/view /2545

Riazi, M., Shi, L., \& Haggerty, J. (2018). Analysis of the empirical research in the journal of second language writing at its 25th year (1992-2016). Journal of Second Language Writing, 41, 41-54. https://doi.org/10.1016/j.jslw.2018.07.002

Richards, J. C., \& Schmidt, R. W. (2010). Longman dictionary of language teaching and applied linguistics ( $4^{\text {th }}$ ed.). Harlow: Longman.

Sasaki, M. (2000). Toward an empirical model of EFL writing processes: An exploratory study. Journal of Second Language Writing, 9(3), 259-291. https://doi.org/10.1016/\$1060-3743(00)00028-X

Sun, Y.-C., \& Chang, Y. (2012). Blogging to learn: Becoming EFL academic writers through collaborative dialogues. Language Learning \& Technology, 16(1), 43-61. http://dx.doi.org/10125/44274

Tillema, M., Van den Bergh, H., Rijlaarsdam, G., \& Sanders, T. (2013). Quantifying the quality difference between L1 and L2 essays: A rating procedure with bilingual raters and L1 and L2 benchmark essays. Language Testing, 30(1), 71-97. https://doi.org/10.1177/0265532212442647

Warschauer, M. (2002). Languages.com: The Internet and linguistic pluralism. In I. Snyder (Ed.), Silicon literacies: communication, innovation and education in the electronic age. London: Routledge.

Xinghua, L. (2010). An investigation of Chinese university EFL learners' knowledge about writing. Language Studies Working Papers, University of Reading, 2, 51-63.

Yingli, W. (2012). A descriptional study on differences in L1 and L2 academic writing. International Journal of English and Literature, 3(5). https://doi.org/10.5897/1JEL11.118

Yoon, H. (2008). More than a linguistic reference: The influence of corpus technology on L2 academic writing. Language Learning $\mathcal{E}$ Technology, 12(2), 31-48. http://dx.doi.org/10125/44142 
Zabihi, R. (2018). The role of cognitive and affective factors in measures of L2 writing. Written Communication, 35(1), 32-57. https://doi.org/10.1177/0741088317735836

\section{Author's Brief CV}

Abdul Syahid has been an EFL teacher since 1995. After teaching at senior high schools in Sepang and Sampit, he joined the Department of English Language Education, Faculty of Teacher Training and Education, Institut Agama Islam Negeri Palangka Raya in 2018 to pursue his teaching career. Besides second language writing, his areas of interest include Computer Assisted Language Learning.

\section{Appendix 1: Writing strategies interview}

\section{INTERVIEW QUESTION LIST}

(Adapted from Nguyen (2009) and Prijambodo (2009))

Questions for semi-structured interviews with participants may change in detail as a result of initial analysis of the responses to the questionnaires. However, at this stage the questions anticipated to be asked are as follow:

\section{About the questionnaire:}

1. Can you explain if there is anything in the questionnaire making you confused?

2. Could you describe any writing strategies you use not mentioned in the questionnaire?

3. Could you explain why you use this (or these)?

\section{About writing:}

1. When did you start to write an EFL academic genre?

2. What did you think the first time you write in English as a First Language?

3. What topics do you prefer to write?

4. Besides writing academic genre, do you write other texts in English to practice EFL writing skill?

5. How often do you practice EFL writing?

6. Could you explain what you do to practice writing in English?

7. Can you tell me the phases of your writing process?

8. How much time do you usually spend each time you write an article?

9. What actually determines the duration of your writing an EFL academic genre?

10. What are the difficulties you usually face when writing an EFL academic genre?

11. How did you cope with the difficulties? 
12. When you find yourself of dry mind, lacking ideas when writing, what do you do?

13. Could you tell me what you do to help you with the generation of ideas before you write?

14. Do you read about the topic that you are going to write about before writing?

15. Could you explain why?

16. Could you tell me whether you think in English or in your first language when you write?

17. Could you explain why you do this?

18. Do you write immediately in English or translate from your first language?

19. Can you explain why you do this?

20. Can you describe and explain any factors that affect your English writing (where you write, topic, etc.)?

21. Which is the most impressive article among the articles you have written? Why and how did you write it?

22. What are some supporting factors that drive you to keep on writing an EFL academic genre? 